\title{
South Africa's Weekly Media: Front-Page Reporting 9/11, Preventing Islamophobia
}

\author{
Muhammed Haron \\ HARONM@UB.AC.BW
}

\section{Abstract}

New York's twin tower bombings, popularly referred to as 9/11, are regarded as a watershed period in world affairs. It happened at the cusp of the new century and its impact, since then, has been enormous, for it radically changed many aspects of human life. Both the print and the electronic media were pivotal in these changes. Besides shaping the way that communities perceive others, it also influenced the manner in which communities are dealing with one another. Since a radical Muslim group was blamed for this dastardly deed and since Muslims were implicated for this reprehensible act, the secular media expectedly placed the Muslims - in majority and minority settings - around the world under the spotlight. The media's negative portrayal and reporting about Muslims did not only contribute towards a tendentious relationship between the media and the Muslims but it also contributed towards the spread of Islamophobia. This thus caused Muslims in both majority and minority settings to adopt a skeptical view of the role of the secular media. Considering these developments, this essay's focus turns to the South African print media that reported and analyzed their reporting of this event during that period. Since it is beyond this essay's scope to look at all the country's daily and weekly tabloids, it restricted itself to two widely circulated South African weekly newspapers, namely the Sunday Times and Mail \& Guardian. It first describes and discusses their front-page reports as they captured the tragic $9 / 11$ event, before it reflects on their editorials columns providing one with insights into the respective editors' understanding of this event and their perceptions of Muslims nationally and global- 
ly. Being a purely textual study, it conceptualizes Islamophobia as the essay's conceptual frame.

Keywords: South Africa, Muslims, Mail \& Guardian, Sunday Times, Islamophobia, 9/11

\section{Introduction}

During the mid-1990s, when South Africa transformed itself from an apartheid state to a democracy, it adopted a Constitution, guaranteeing and safeguarding freedom for its proactive citizens and diverse establishments. Its revamped legal system ensured that religious communities, who formed an integral part of its citizenry (Henrico 2019), and the media industry, which was used as one of the instruments to back the nation-building project, benefitted from these outcomes (Kandjii 2001; Tomaselli \& Dunn 2001).

In fact, South Africa's democratic government used its socio-legal instruments to stimulate its media industry to expand and diversify. It, for example, opened the airwaves that granted various socio-cultural and religious communities to set up community radio stations. When this was realized, these stations competed with the state-run stations and they complemented the vibrant print media sector. Alongside that, the government also assured that all its religious communities - majority and minority traditions could, among others, establish their educational institutions and social welfare organizations to advance their socio-cultural interests. South Africa's Muslims, though a minority within the country's dominant secular cum Christian surroundings, are among those that so far made use of their given freedom. Some of the representative groups invested funds to found Muslim radio stations and others set up digital sites to make themselves visible through cyberspace networks (Vahed \& Jeppie 2005; Haron 2018).

All these developments demonstrated that the South African democratic setting - despite its internal hiccups and challenges - continues to be a very supportive and dynamic environment. It is for this reason that South Africa's Muslim community (along with others) and the media industry have been active contributors to South Africa's national identity - one that remains a work in progress. Together with them, it may be argued that the Muslim community and the media were and continue to be vital components in 
building a democratic South Africa - a country that works hard and still tries hard to overcome its deeply racist past. However, this essay has no intention to evaluate their roles in this nation-building process.

The essay's purpose is different. It has set itself a two-pronged objective: The first is to assess how selected South African weekly newspapers reported and captured the catastrophic 9/11 event, questioning whether it contributed towards the rise of Islamophobia in South Africa. Together with these reports, the second objective is to examine and comment on their respective editorials. In addition to this, the essay rounds off with a brief comparative reflection of both newspapers and assesses whether the two have contributed to or prevented the spread of Islamophobia within the South African context. Before addressing its main ingredients, it prefaces the discussion by reflecting on 'Islamophobia' as its conceptual frame.

\section{Islamophobia: Its Context and Definition}

For the past three decades or more (ca 1990s-2010s), the contemporary secular-oriented Western world and its diverse populations have observed an increase in 'hate crimes' against the Muslim communities (Bayrakli \& Hafez 2018; Githens-Mazer \& Lambert 2010; CAIR 2010). In the proverbial West, various studies have turned its focus on hate crimes. Some, however, have also included xenophobia and anti-Semitic detractors. Nonetheless, these studies proved that Anti-Muslim sentiments have been perpetuated via the Islamophobia industry led by several Islamophobes such as Jihad Watch's Robert Spencer and Daniel Pipes' Middle East Forum during the mentioned period (cf. Ali, Clinton, Duss, Fang, Keyes, \& Shakir 2011:4-7; Lean 2017: 204-205; Smith 2013:7-8). These scholars and activists were further supported by many ex-Muslims such as Ayaan Hirsi Ali, who migrated from the Northeast to Europe/USA (cf. Lean 2017:167-168).

All of them have reinforced their prejudicial attitudes through their discriminatory statements and practices against Muslims and Arabs. Even though they and others are fully aware of the fact that there were and are Arab Christians and Jews, they continue to vent their feelings against Muslim and Arab religio-cultural practices. In this regard, one has to mention en passant Edward Said's seminal work Orientalism (Said 1987) - a text that 
tangibly records the biased anti-Arab/anti-Muslim approaches that were pursued by European scholars towards the Orient over the past two centuries.

Despite Said's intellectual interventions, countering and showing up these orientalists for their negative portrayal of the 'Other' (i.e. Muslims and Arabs), his writings were unable to stop the emergence of the 'Islamophobia industry' - an industry that Ali and his fellow researchers discuss in their informative report (Lean 2017; Abadi 2018). Saeed, who has studied this phenomenon in the UK, has extracted an apt quote from Sayyid's 2010 study (Sayyid 2010) and commented on it. She does not only briefly locate its historical roots but phrases it as follows: 'Islamophobia is situated within an ideological Orientalist struggle, where [a]t the heart of Islamophobia is...the maintenance of the "violent hierarchy" between the idea of the West [and all that it can be articulated to represent] and Islam [and all that it can be articulated to represent]' (Saeed 2016:5).

Saeed has therefore underscored the strong connection between these two terms. The orientalist project has since been taken up by an array of Islamophobes and the flourishing Islamophobia industry (Lean 2017). She (Saeed 2016:6) correctly points out that it was the 1997 UK-based Runnymede Trust's groundbreaking report that gave the term its 'institutional importance' (cf. Lean 2019:12). Factoring in these developments and the broad but decidedly brief historical context, one should not overlook the fact that, though Runnymede Trust's definition and explanation was generally approved as part of the English language's vocabulary list since 1997, there were other scholars such Jocelyn Cesari (2006) that challenged its use (cf. also Zempi \& Awan 2019). Beside these critics' counterviews, there are also those who debate and refute its validity, according to the edited annual report of Bayrakli and Hafez (2018:6).

Since these different opinions are not central to this essay, I just want to refer to one specific definition before turning to the essay's main concern. Here it draws upon the working definition of the University of California Berkeley's (UC-B) Islamophobia Research \& Documentation Project, a structure that has also established the annual Islamophobia Studies journal that is issued by the Centre for Race and Gender at UC-B. According to the project's leaders, led by Hatem Bazian (n.d.), 'Islamophobia is a contrived fear or prejudice fomented by the existing Eurocentric and Orientalist global power structure'. They (Bazian n.d.) add that 
[i]t is [a phenomenon that is] directed at a perceived or real Muslim threat through the maintenance and extension of existing disparities in economic, political, social and cultural relations, while rationalizing the necessity to deploy violence as a tool to achieve 'civilizational rehab' of the target communities [Muslim or otherwise].

They also underline that 'Islamophobia reintroduces and reaffirms a global racial structure through which resource distribution disparities are maintained and extended' (Bazian n.d.; Abbas 2019:36).

Taking this detailed definition into account as well as the post-9/11 period that witnessed a conspicuous presence of Muslims in Europe and the USA, it becomes obvious that the concept (was and) remains inextricably tied to the orientalist project. According to the Islamophobes, these Muslims' increasing visibility was perceived as a major threat, one that should be stopped by any means necessary. Currently, in the post-Cold War era, these socio-political developments are falling in line with the heavily critiqued 'clash of civilization' thesis of Samuel Huntington $(1993 ; 1997)$. This proposition gave credence to the idea that, from the 1990s onwards, the West would inevitably encounter Islam and its adherents, and they would appear as potential threats, as the West expanded its secular democratic policies, while extending its reach to environments far beyond its own geographical locations. All the highly secular societies that subscribed to this project imbibed and perpetuated stereotypical opinions of the 'Other'. These views have not only been conveniently churned out by the prejudicial think tanks such as Jihad Watch, but it has also been circulated by the influential secular media that acted as the think tanks' natural allies in their stance towards Islam and the Muslims (Ali et al. 2011).

Speaking about the media and its influential status, it is the studies of inter alia, Said (1981) and Poole (2002:162-167) that reveal the media's provocative position in world affairs in general, and the Muslim heartlands in particular. Its editors and their journalists' sensational news items stoked what the Runnymede Trust (1997:4) defines as an 'unfounded hostility towards Islam [and Muslims]'. These newspapers' editors have thus created a toxic bond between the media and the Muslim communities living in and outside the West. 
The Muslim communities as well as other people in the world expectedly raised their concerns about the biased media reports, arguing against the media's nefarious role in unwantedly spreading Islamophobia. They, of course, realized the media's highly powerful position globally and they were fully aware to what extent the media persuasively influenced millions of people's perceptions about them and their socio-religious and cultural habits. As one turns to South Africa where its Muslims form an integral part of its multireligious and multicultural landscape, the question that confronts us is: Has South Africa's vibrant secular media acted in the same way as their counterparts in Europe and the USA in the aftermath of 9/11, fomenting feelings of Islamophobia towards the Muslim community? To answer this question, the focus shifts to this community and the media in South Africa.

\section{South Africa's Muslims and the Media}

\section{The Muslim Community}

Reference was made in the introduction to the fact that the Muslims, as one of the religious communities in South Africa, have benefitted and taken advantage of their conditions in this country's democratic environment. Being a minority within a sizeable population of about 60 million people, according to the 2020 demographic statistics (Worldometer n.d.; cf. Schoeman 2017; Haron 2003), the Muslims have been resilient, while they, like any other group, remain a dynamic community despite their internal squabbles and external challenges (Vahed \& Jeppie 2005; Haron 2018).

Over the past centuries, their members' contributions towards various sectors of the South African society have been notable. They made inputs to, inter alia, the building industry, the clothing segment, fishing division, and cultural sector. However, just like other religious communities, they have had elements that differed from the majority and that acted outside the norm. Though small in numbers, radical groups such as People against Gangsterism and Drugs (PAGAD) did not only adopt an extremist agenda to achieve their socio-political objectives, but they were also very vocal.

During the late 1990s, the Western Cape society was unsettled because of the violent behavior of this predominantly Muslim group, 
established in 1995 (Baderoon 2005:86). Consequently, the society witnessed spurts of Islamophobic outbursts in the media. This was quite evident when the local government had major difficulties in restricting PAGAD's activities (Baderoon 2005:89-91). Though the organization started as a proactive protest group, it developed itself into a vigilante group and subsequently into an extremist outfit that used extreme measures to counter gangsters and drug dealers. Because of these methods, the media published news items that gave the impression that the whole Muslim community supported and identified with PAGAD's actions. Even though this was not the case, the community was implicated in not having sufficiently spoken out against the organization's treacherous tactics (Gottschalk 2005:3-4).

Baderoon (2005), however, demonstrates to what extent the media reinforced the stereotypical perceptions of Muslims. The outcome of this was twofold: It resulted in the existence of a quarrelsome liaison between the South African secular media and the Muslim community, and it forced the Muslim media to challenge the reports that were circulated in the secular media. Since Asmal (2008) and Ebrahim (2008) both undertook related studies, one should view them as complementary texts. That being the case, it is now opportune to turn to the two newspapers that reported on the $9 / 11$ event by assessing whether their respective reports have added to the abovementioned frictional relationship and whether they have contributed to the spread of Islamophobia in South Africa.

\section{South Africa's Newspaper Industry}

Compared to the newspaper industry on a national level, it can be argued that South Africa has had and continues to have one of the most robust industries. In the print sector, the society is served by a plethora of newspapers in the cities and towns. Over the years, dailies and weeklies have fed these communities with information about the country and other parts of the globe (Tomaselli, Tomaselli, \& Muller 1987; Hadland 2007). From among its popular weekly newspapers, the Sunday Times and Mail \& Guardian stand out as both these papers have already left their footprints in South Africa (Jackson 1993; Switzer \& Adhikari 2000; Hadland 2007).

The two newspapers both have a long history in the South African media industry with the Sunday Times being the oldest (Dreyer 2006). This newspaper has celebrated its centenary a few years ago. The Mail \& Guardian, which is much younger, began its life as The Weekly Mail (Merrit 
\& Saunders 2000) and, like the Sunday Times, it has made inroads into the Southern African reading market where its newspaper reports are eagerly read and devoured. Accordingly, the two newspapers spread their wings throughout South Africa, creating their respective spheres of influence and niche markets.

When comparing the two newspapers in terms of their 'quality' and 'status' in the eyes of their readership, the evidence suggests that the Sunday Times enjoys a greater degree of circulation because of its mainstream contents. It decidedly targets the non-elite reading market, and for that reason it reaches a wider audience. The Mail \& Guardian's contents, however, have been crafted to meet the needs and interest of readers who hail from middleand upper-class homes. Most of the readers, if not all of them, are from the educated and socio-politically informed communities within the South African society (De Waal 2010).

Based on these few facts, the differences pertaining to their approaches, understanding, and interpretations on an assortment of issues in the local arena as well as on the global level, are glaringly vast. One example that demonstrates this quite well was when they reported on the extremely tragic and deeply sad event that occurred on USA soil on Tuesday, September 11,2001 . This day and event have since been famously referred to as $9 / 11$ (cf. Hoover 2006:236). When one googles the reports as captured in the South African media at that time, one is able to observe how the event was depicted and presented by the different papers (Botha \& De Beer 2007). In this regard, the brief but important study of Tayob (2002:20-25) illustrates to what extent South African Muslims' lives - like those of everyone else have been affected and changed after the 9/11 occurrence.

Since very little research - except for the respective essays of Baderoon (2005) and Botha and De Beer (2007), as well as the theses of both Asmal and Ebrahim being written in 2008 - has been undertaken to assess the media's reporting strategies regarding that notable event, this essay sees itself as a contribution towards filling a gap. It is perhaps necessary to state that even though 9/11 might be regarded by some as a dated event, many studies subsequently and during the past few years reveal its devastating impact and disturbing repercussions (cf. Zempi \& Awan 2019). These studies underline its global reach. The communities in South Africa were also affected by it. While several American and European studies evaluate it from a variety of angles, this essay, like numerous others globally, restricts itself to its national 
media by assessing their reports. However, in the process of doing this, it questions whether these reports have been key in fomenting and giving rise to Islamophobia.

Therefore, instead of scanning (all) the daily papers, this essay confines itself to the two mentioned weekly papers. Since the essay is not able to discuss all aspects related to media reporting and since it cannot deal with all the variables (such as securitization and disaster management) related to the event, it limits itself to particular sections of the newspapers. It evaluates the newspapers' front-page articles/reports, and it analyzes their respective editorials. The reason for examining these sections in the respective newspapers may be attributed to the fact that the lead stories on the newspapers' front pages and their editorials constitute the main ingredients of these papers or, for that matter, any other paper.

\section{The Newspaper: Its Front-Page Reports and Editorials}

Anyone reading or studying a newspaper usually first browses the front page before flipping through the other pages to see the editor's comments or to find out what the columnists or cartoonists have captured in their columns/ cartoons. Though the two (i.e. front-page stories and editorials) may be viewed as separate texts, it shares a relationship, for a paper frequently splashes the most newsworthy items on its front page and then the editor comments on it. Simultaneously, the cartoonist of the paper also captures the idea of the main story in their quirky and, at times, sarcastic manner. For the sake of keeping it brief, the essay summarily touches on the two issues before assessing the specific newspapers.

\section{Front-Page Features}

According to media studies specialists such as Broder (2000), the front page is the 'showpiece' of a newspaper in that it brings into focus what the editor or editorial board considers to be the most important 'hard' story of that week (and not of the day as would be the case when focusing on dailies). Conboy (2007) points to three functions which are served by headlines: a) It summarizes the main news; b) it grabs a reader's attention; and c) it indicates the paper's contents. In this instance, the lead story was the 9/11 event. It was indeed an event that not only grabbed everyone's attention, but it sent shockwaves throughout the USA and the Western world, and in this way, it engulfed the globe. 
It was an occurrence that not only received instant coverage by all the media internationally, but it was also headline grabbing hard news for all the local newspapers in South Africa. This clearly illustrates that this USA incident has impacted deeply on each and every nation and this caused much discomfort in everyone's socio-political and economic lives - something that was not readily experienced before, and an event that has a snow-balling effect on every sector of society.

The 9/11 calamity had an indelible influence on world affairs as one of its outcomes was the adoption of new policies with regards to fighting extremism all over the world. The media, as the respected edited volumes of both Zelizer and Allan (2002) and Pludowski (2007) show, were in the vanguard. These policies, in turn, affected almost every segment of human life.

South Africa was no exception, as this has been witnessed, inter alia, in redrafting the South African Anti-Terrorism Bill, the tightening of laws pertaining to financial transactions, and the imposition of new rules and regulations when it comes to travelling locally or abroad, and it also gave rise to Islamophobia (cf. Vahed \& Jeppie 2005; Buccus \& Nadvi 2006). Many of these issues were reported upon and appeared as front-page reports. Since it was viewed by the editors as critical themes, it was natural that they would pick on it by offering their critical comments.

\section{Editorial Explications}

Though the editorial page compliments the front page in a distinct manner, it differs from it in that it, according to Sagheer (n.d.), is seen as the 'heart and soul of the [entire] newspaper'. Bonyadi and Samuel (2013:2-3) refers to Van Dijk (1995) and Bell (1991), where the former underlines that the newspaper editorial should be viewed as an opinion text, while the latter underscores the view that it is a significant genre within the newspaper sector, for it is indeed different from the general news discourse: It is one that offers critical comments and provides essential evaluations of current affairs.

The editorial column is a special entry into the newspaper that specifically deals with salient hard and soft news reports. Le (2010:1) remarks that the editorial 'offer[s] reasoned views of the world in slices of no more than 500 words each. Some of them are also superb pieces of writing'. The editorial column is characterized by incisive and perceptive comments/ analyses rather than an objective reporting of factual information in relation to the relevant lead story. 
When reflecting on the editorial comments and analyses of both weekly newspapers, it becomes quite evident that both papers' editors were conscious of the effect that the 9/11 event had on global affairs. Because of its impact and effects, they shared their perceptive thoughts on, among others, the 'war on terror' campaign that George Bush Jr., while in office, initiated and imposed upon each nation-state across the globe.

At this point, it is of interest to note that Bonyadi and Samuel (2013:2) refer to Hall's seven categories that are considered useful when analyzing an editorial column (Hall 2001). Hall catalogues the following: Criticism, attack, defense, endorsement, praise, appeal, and entertainment. After having scanned each of the editorials, one observes that the editors made use of one or a combination of the mentioned variables. They, for example, criticized the heinous act and, at the same time, cautioned the US administration not to embark on a war on the Afghani people who were basically innocent of this crime. To these, the essay intends to return when commenting on the two newspapers' editorials. At this juncture, it briefly addresses a prefatory note and an afterword that added to the attentiongrabbing and persuasive headlines.

\section{South Africa's Weeklies: The Mail \& Guardian $(M G) \&$ the Sunday Times (ST)}

Before plunging into the special issues of the Mail \& Guardian $(M G)$ and the Sunday Times (ST) that appeared immediately after the fateful 2001 catastrophe, the essay takes a slight detour by briefly reflecting on two advertorials that coincidently tied in with these headlines. The two appeared in $M G$ and $S T$ respectively. Since the first appeared in $M G$ and the second a week after in $S T$, the two correspondingly appeared as 'a preface' and 'an afterword'.

\section{MG's Accidental Preface and ST's Planned Afterword to the 9/11 Affair} $M G$ featured in its August 31 to September 6, 2001 issue a two-page advertorial (MG 2001a:28-29). This was generously sponsored by the USA's Centervill (VA)-based NGO, called The Coalition for the Defense of Human Rights (CDHR). The NGO labelled the advertorial: 'Radical Islamism = Racism $=$ Genocide'. They targeted all those who were going to attend the 
Durban-scheduled World Conference against Racism, Racial Discrimination, Xenophobia and Related Intolerance (WCRRDXRI). The NGO issued it without offering a clear definition of 'radical Islamism'. However, from its signatory's perspective, it was bent on conveying its message about racists (in outlook) and genocidal (in practice).

The advertorial pleads with the 'Conference [organizers and attendees] to recognize [the emergence and development of] Radical Islamism as a totalitarian movement that aimed at establishing a worldwide [intimidating] Radical Islamist state' (MG 2001a:28-29). It refers to the possible formation of an undemocratic state that would challenge and oppose the traditional Muslim states, and it describes it as a threatening state that subscribes to a puritanical agenda - one that is based on its political leadership's interpretation of their (i.e. Islam) primary sources.

Since South Africa's Muslim organizations were sensitive to this and related advertorials, the Pretoria-based Human Rights Foundation (HRF) also issued a full-page advertorial. This, however, did not appear in $M G$ as expected but in a later issue of $S T$ (September 30, 2001 - ST 2001c). It was decidedly titled "Concept of "Holy War" or "Jihad" since HRF's main purpose was to set the record straight by offering a correct understanding of jihad - a concept that, they argued, has been controversially conceptualized by Islamophobes. On top of that, the HRF's author also wanted to place the concept within its rightful socio-historical context.

Both advertorials triggered questions that one would like to pose. The first is: Was CDHR's imported advertorial an (un)intended slip of Islamophobia using an international platform to drive home to everyone its concern about the presence of radical Muslims and the possibility of them forming and envisaging an 'Islamic' state that would be pursuing an extremist Muslim agenda in the global democratic environment? The second question is: Was HRF's advertorial a planned afterword or a reply that staved off a possible Islamophobic outpour within the South African context?

One may wish to argue that the CDHR advertorial, which was intended for the WCRRDXRI attendees, had a larger $M G$ audience in mind with the hope of influencing and triggering a debate at the international forum. While it cannot be denied that the advertorial contained elements of Islamophobia, it did not have its intended effect since the newspaper served an educated readership that was not easily convinced by its arguments. It is therefore difficult to say whether it reached all the conference's delegates. 
Even though its contents were connected to the 9/11 disaster, it seems that it was lost because of the tragedy that caught the communities around the world off guard.

Since that advertorial did not go unnoticed, the HRF issued an advertorial that countered it, and this appeared in $S T$ and not in $M G$ as thought. HRF's advertorial, it may be argued, neutralized the one by CDHR. One may venture to state that within the South African context, while the one advertorial appeared as an 'accidental preface' to the 9/11 event, the other appeared as a 'planned afterword'. These, consequently, balanced the unplanned public discussion via the pages of these two weeklies.

\section{Mail \& Guardian: Its Reports and Editorial}

Getting back to the main focus, one may add that the 'accidental preface' and the 'planned afterword' should be seen within the $9 / 11$ context. Bearing in mind the pre- and post-9/11 scenarios, the essay turns to $M G$ 's front-page headlines.

\section{$M G$ 's Front-page Reports on 9/11}

$M G$ (2001b) devoted 14 pages to the tragic occurrence. In this 'special' issue, the editor and his team of journalists cover this lead story from a variety of angles. It has a portrait of Osama bin Laden emblazoned across the front page with the bold headlines screaming below the newspaper's masthead, 'WANTED'. At the foot of the photograph, it inscribed the words, 'DEAD OR ALIVE', and this is followed within brackets by the words, 'GUILTY OR NOT'.

At first glance, the picture conveys the impression that Osama showing his fist-long beard and wearing his white turban and clad in a khaki, army-type jacket - was indeed the person who master-minded this treacherous, inhumane act, but after having had another look at the photo and the page, it forced one to reconsider one's position by reaching a slightly different conclusion. The words 'GUILTY OR NOT' at the bottom of the photo cause one to think otherwise. In other words, he might not be guilty as stated by official US documents and newspaper reports.

In $M G$ 's inside pages, a few articles, however, point out that the US administration has already considered Osama guilty for having been one of the key figures behind this terror attack. The newspaper, moreover, asserts by suggesting that the US administration's accusations, which were based on its 
knowledge about this Saudi philanthropist and his support group, Al-Qaeda whom the CIA had trained and armed during their campaign against Afghanistan's communist regime (Lean 2017:43-45) - should not be taken at face value. The articles argue that the issue should be examined thoroughly in light of the USA's role in world affairs in the past and during the present (Lean 2017:43-45). These points are, in fact, stressed and elaborated on in the lengthy and carefully argued editorial of the paper. Herein the editor reminds his readers of the comments by Herman and Chomsky that underscore the notion of Manufacturing consent (Herman \& Chomsky [1988] 2002) as well as Said's earlier publication Covering Islam (Said 1981).

\section{$M G$ 's Editorial}

In the opening paragraphs of the lengthy editorial, which is titled, 'No challenge to US' (MG 2001a), it states that some South Africans - making indirect reference to the Muslim community and perhaps left-wing leaning groups who were the most critical of USA policies towards the Middle East argue that the 'US had its just desserts' (cf. also Tayob 2002; Botha \& De Beer 2007). It also states that some people hold the notion that it 'marked the beginning of the end of the "American Empire".

The editorial argues differently. It states that the US economy and its political position have not been 'dented in a fundamental way'. This, it contends, is 'a fantasy' and that 'the world has been left more dangerous'. The editorial further rationalizes along the following lines: 'Assuming that the killers are Islamic militants - and the suicidal nature of the attacks suggests this - it is important to realize that theirs is a minority version of Islam' (MG 2001a). Here the editor does not only critically question the USA's policies but clearly expresses the view that if the act was perpetrated by radical elements from within the house of Islam, then they do not speak for the majority. The editor thus essentially counters the Islamophobes' perspectives.

The editorial categorically clears the Muslims who unreservedly detest and reject such tactics. This point is made in numerous 'letters to the editor' as these appear in subsequent issues, being echoed in articles that also feature in Muslim newspapers such as Al-Qalam (2001). It confidently maintains that Muslims generally - except for a handful of extremists usually appropriate and interpret their primary texts not to defend such atrocious acts but to condemn them. In this regard, the editorial makes an 
immediate reference to the 'fundamentalist' Muslim Brotherhood (MB) that has publicly condemned these attacks. As a genuine representative of Muslim opinion in the Muslim heartlands, the MB opined that these acts contradicted 'all human and Islamic values'.

It, however, draws our attention to the USA's 'obsessive focus' on the alleged terrorist mastermind, Osama bin Laden, his harbingers, and the Afghanistan Taliban government. It, moreover, cautions - for what it is worth - the USA's intentions such as wanting to blast Afghanistan 'back to the Stone Age'. From the editor's stance, the 'terror attacks on the US will not stop' if the USA administration does not mend its policies (ST 2001a).

The editorial (ST 2001a) reminds the readers that the root problem is embedded in the fact that the USA is hated by people in certain parts of the world, particularly the Arab world 'for the arrogance of its power' (ST 2001a; cf. Botha \& De Beer 2007; Smith 2013). This viewpoint is, furthermore, based on many factors, like: The USA does not recognize the International Criminal Court (ICC); the USA did not sign the Kyoto Treaty of Climate Change; and it conveniently withdrew its representative from the UN racism conference.

The USA, the editorial stresses, arrogated itself above all international regulations and has been oblivious of the suffering that its actions have caused when it blockaded Iraq for many years in the 1990s and when it stood by without lifting a finger to prevent the Great Lakes genocide from happening. The editorial concludes by offering its advice to a pompous, democratic USA regime. It basically states that the USA, as the only global power, should adopt a sensitive approach towards deeply aggrieved communities such as the Palestinians and others around the globe. It adds that the USA should avoid any form of military action because this will not assist in attaining ultimate 'sustainable peace' and bring about stability within the world system. Considering the editor's opinion as captured in the editorial, he reminds us of the variables that Hall has catalogued (cf. Bonyadi \& Samuel 2013:2).

While we may commend the $M G$ editor for having boldly articulated his position vis-à-vis the USA policies and acts, one doubts whether the USA administration would seriously consider the views of this editor and others like him, knowing that it regards itself as the only super-power and that it considers to be the only 'global cop' in the affairs of the world. One should also make the point that during and in the aftermath of the tragic 9/11 


\section{Muhammed Haron}

happening, it was well-nigh impossible for anyone to offer any sound advice to the USA administration. Its political leadership had already cast aside the sober opinions of an array of policy makers, scholars, and editors. It has, as a matter of fact, psychologically prepared itself to hound out Osama from Afghanistan, attack the country, and bring about a regime change by replacing the Taliban government.

In fact, there was no discussion as to whether Osama was guilty or not, and they did not think twice about the implications of such a war in the Muslim heartlands. Even though everybody, including South Africans, represented by religious bodies and civil society groups, were generally against the war (Tayob 2002; Botha \& De Beer 2007), the US administration insisted on its right of defense. It defiantly and adamantly went on to bombard Afghanistan, arguing that their intention was to find the culprits who had committed the dastardly deeds (Tellis 2004:70-71; Botha \& De Beer 2007:288-289).

Even though none of the Afghanis - except fighters that were associated with Al-Qaeda - were involved or implicated in the act, the USA had no reason to attack that country other than needing to apprehend Osama bin Laden who, they maintained, was the master brain behind the attacks. At this point, the focus switches to $S T$.

\section{Sunday Times}

Earlier in this essay, it was confirmed that $S T$ is the oldest weekly newspaper in the country. It is qualitatively different from $M G$ because of its coverage and target audience. $S T$ subscribes to the motto '(t)he paper for the people' and this appears below its blood-red masthead that appears on each weekly issue of the newspaper.

When the 9/11 catastrophe took place, ST devoted most of its pages to the event in its September 16, 2001 issue. It even covered the issue in the business section, since the outcome affected the economic affairs of the world. In fact, almost each page had images/pictures, accompanied by a series of articles that seriously reflected on the existential situation as well as the aftermath of the tragedy.

\section{ST's Front Page}

On the issue's first page, the imprinted headlines boldly read 'COUNTDOWN' (ST 2001a). This emboldened word is referring to the USA's 
pending military action against those that it had identified and accused of the atrocity. The one picture shows a flag that was hoisted above the twin tower rubble. It captures fire personnel and other workers who carefully scoured all the areas for possible survivors and victims who died or who were still alive under the debris.

On this picture's right side, the editor has inserted the photos of Nelson Mandela and Henry Kissinger. The latter is quoted to have said that 'terrorism should be rooted out', while the former emphatically remarks that 'Arabs are not the enemy'. At the end of the page, an article that flows over onto the issue's third page animatedly describes the USA's eagerness to fight the 'barbarians' for their cowardice and their heinous acts. The article mentions Bush's cabinet as well as the National Security Council's definitive resolve to support the world community in combating terrorism across the globe (ST 2001a).

\section{ST's Editorials and Essays}

The editorial, which is titled 'Now the world needs vision' with a Zapiro cartoon accompanying it, echoes the Bush administration's position, stating that 'Tuesday's attack on the symbols of the US's financial and political power was "an act of war" (ST 2001a). The editorial states that, since that moment, the world was 'a different place' in which humans effectively changed how they conduct 'defence, diplomacy and politics' (ST 2001a).

The editor further proffers the view that, engaging in warfare, is no more being fought according to conventional rules as had been the case in the past. It repeats the views of the US media that opined that the war was increasingly being fought 'by fanatics who owe blind loyalty to cause and leader'. This is, of course, with reference to Osama bin Laden whose name is not mentioned and who, the editor seems to also believe, was behind this heartbreaking event.

He later states that '[a]ll civilized people will agree that these terrorists must be hunted down, using the rule of law that sets democrats apart from tyrants' (ST 2001a). Here the editor indirectly cautions the Bush administration to remain, as a democrat, within the rule of law as he and his cabinet have listed their strategic options. The editor mentions that " $\mathrm{t}]$ hose who provide them [i.e. the terrorists] with funding and shelter must be subjected to the same sanctions' (ST 2001a). He concludes that the 'peace and prosperity enjoyed by the US and Europe can only be protected by 
extending it to those in the developing world' (ST 2001a). However, the editor argues that this can only be done if the First World writes off the debt of the Third World. He advocates the view that the world desires political leadership in world affairs that are non-arrogant and that 'seeks to ensure the long-term security of the world by extending prosperity to all its people' (ST 2001a).

The editorial is, however, accompanied by two other insights. The first is by William Pfaff - an International Herald Tribune contributor - who comments on the USA's obsession with high tech that failed in this instance when it was needed most (ST 2001a). Here quick reference may be made of Justice Malala's regular weekly column titled, 'The wild, wild West' in which he ponders over the disastrous occasion. Malala records that two images that struck him was the World Trade Center's (WTC) workers who waved frantically to be rescued and an oppressed Palestinian boy-child who rejoiced at the news of this event.

Malala then makes two observations: The first is that from among the critics there are those who firmly believe that the USA under the Bush administration had, on that shattering instance, been dished its 'just desserts', while the second is that there are others that express a concern about Bush's warmongering battle cries. In light of these responses, Malala pushes for the pursuance of correct measures that should be considered in the circumstances because the people's feelings are that the act was disgusting and distasteful.

Malala rounds up by stating that '[t]errorism kills the innocent. Africans should condemn it at every turn and should not wait for another Nairobi [or New York]' (ST 2001a). Even though Malala's sensible thoughts did not receive any critical response since they were widely held by many, he was subsequently criticized by readers (in their letters to the editor) for some of his harsh views against the USA's foreign policies towards parts of the developing countries such as Afghanistan and Iraq. Apart from Malala's sharp and well-thought comments on local and international affairs, his inputs are also complemented and supplemented by many articles that have been penned by foreign correspondents such as Andrew Donaldson (ST 2001a).

For this special issue, $S T$ relied heavily on a series of reports, commentaries, and analyses from foreign journalists. This was also the case in the subsequent issue, published on September 23, 2001 (ST 2001b). In this issue, the editor's editorial addresses the fact that '[v]alues [are] under siege' (ST 2001b). Herein, he re-emphasizes - in light of the invasion of Afghanis- 
tan with the intention of the wiping out of Osama bin Laden's terrorist AlQaeda's cells - some of his thoughts that were expressed in the previous week's editorial. He repeats the view that the democrats 'must scrupulously adhere to the rule of law' (ST 2001b).

The editor strongly argues that 'when democrats seem to abandon concepts such as innocent until proven guilty...[t]here is little to set them apart from Osama bin Laden' (ST 2001b). Besides having indirectly criticized the USA and its allies, he also makes a brief reference to Penuel Meduna, the (then) Minister of Justice, and Steve Tshwete, the (then) Minister of Safety and Security, who have reached a joint agreement of revisiting the old apartheid Anti-Terrorism Bill and rewriting it in line with the inter-national developments on the issue. He cautions the two ministers by stating that this exercise may be undertaken if it is in keeping with South Africa's Constitution (Tayob 2002; Botha \& De Beer 2007; Buccus \& Nadvi 2006).

Unfortunately, South Africa, like other African nation states, followed the USA request in amending its laws without thoroughly considering the implications that it would have on the country's future (cf. Hendricks 2020:113). In fact, a few South African Muslims, who spearheaded the group that was against the reformulation of this bill as well as its reintroduction, argued that Muslims would be unnecessarily targeted, discriminated against, and stereotyped by fellow citizens if it be approved. Despite the group's protestations, the bill was revised, adopted, and implemented (Vahed \& Jeppie 2004:276; Buccus \& Nadvi 2006).

Together with the editorial, the newspaper syndicates an article written by Ozdem Sanberk, the director of the Turkish Economy and Social Studies Foundation (ST 2001b). He makes the point that a Western prejudice is fanning the flames of Muslim fundamentalism. Sanberk argues against the stereotypical perception held by many Europeans that Muslims are anti-West and by the same token anti-American/European. He expresses the view that this was 'a dangerous myth' that was continuously circulated and that it needs to be resolved by giving voice to the moderates who have been sidelined (ST 2001b). This is a point made in the $M G$ editorial as well. In fact, he claims that Muslim extremism has been given a helping hand in the West and not in the Muslim heartlands. This paradoxical situation, he reasons, should be remedied sooner or later. 
A somewhat different but related point is made by Phylicia Oppelt in her column on the same page when she lays stress on the fact that 'even aggrieved minorities are Americans first' (ST 2001b). She refers to the AfroAmericans who have been marginalized by the white Americans in the USA. She does not highlight to what extent 9/11 has affected the American Arabs/ Muslims who have been blamed for the dastardly act, even though many publicly sympathized and condemned the act. Powell (2011:96-100) elaborates quite extensively on this matter.

\section{Towards a Conclusion}

As the essay inches its way towards a conclusion, it briefly undertakes a comparative assessment of the two papers in terms of their coverage and their editorial responses. The idea is to see whether the reports and stories have contributed to an increase in Islamophobic behavior among South Africans. Bearing this in mind, one would by now have observed that both newspapers addressed the tragedy from diverse angles with national and international reporters sharing their incisive thoughts.

If one returns to the set of $M G$ articles, it shows that its string of journalists was highly critical of the USA's foreign policies but they, at the same time, severely condemned the inhumane act that was perpetrated. The two papers' lead stories, on its respective front pages, were understandably overtly political and it was indeed attention-grabbing as pointed out by Conboy (2007). In this instance, the two papers critically responded to the USA's political leadership under George Bush Jr.

The 9/11 story, being the lead story, was covered throughout the two papers' 'special' issues and, as mentioned in the sections above, many of the $S T$ journalists who were foreign correspondents, dealt with the issue in their columns and articles. In these, they addressed business matters, health issues, travel affairs, and a range of other topics. From these correspondents' perspectives, each of these topics was deeply/partially affected and directly/indirectly influenced by the outcome of this tragedy.

Even though these articles did not bring 'religion' or make direct reference to the extremist religious organization/group in their columns, an oblique reference was made to Osama bin Laden and Al-Qaeda, his extremist organization. It was considered an accepted fact that its members (i.e. the 
perpetrators) - some of whom were fighters that resided in Afghanistan belonged to and represented the Muslims. The unintended consequence of these correspondents' reports seems to have faintly ignited Islamophobic feelings among those who uncritically read their columns and essays. So, while it may be argued that their ideas or Islamophobic thoughts were not overtly and openly expressed, they covertly and subtly articulated it. These $S T$ articles thus differed to some degree from those that appeared in $M G$.

When browsing through their respective editorials, it may be assumed that the editor of $S T$ was somewhat less critical regarding certain aspects and that the $M G$ editor was much more vocal and critical. In fact, he made it quite clear that the act was cruelly executed by a fringe extremist group that emerged from within the Muslim society, although he hastily added that the majority should not be blamed and held responsible for the heinous crime committed by a handful of extremists (MG 2001b).

This response may be used as proof that this editor and $M G$ were not at any stage willing to sow any seeds of Islamophobia. Considering this approach and explanation, one may further underline that he and his paper were among those that prevented the spread of Islamophobia since they were aware that it was a highly emotional period and that they had to adopt a cautious approach. This stance echoes the findings of Ebrahim (2008:64) referring to the greater Cape Town daily newspaper, Cape Argus, which adopted a similar approach. This underlines that its editor was sensitive in the paper's method of reporting.

As we bring this essay to a close, we may add that since there was ample evidence that suggested that the USA prepared itself to attack Afghanistan, where Osama bin Laden and Al-Qaeda were stationed, the two editors politely cautioned the USA not to overreact. They politely appealed to the US that their planned war on Afghanistan should not be considered an option in the circumstances. However, despite their appeal, the US administration went to war by invading Afghanistan as well as Iraq in 2003 (Botha \& De Beer 2007:288-289, 293).

That said, after having carefully studied these two newspapers' attention-grabbing headlines (on their front pages) and critical editorials, one may conclude as follows: First, these newspapers, unlike their counterparts in the USA and Europe, differed from them in their reports and assessments, even though they vehemently condemned the criminal act. Second, having been a gravely sensitive issue, they avoided adopting a judgmental stance 
towards the global Muslim community. As was already stated, the editors did not point fingers at the Muslims for this crime but, like everyone else, considered the small extremist group (Al-Qaeda) to be guilty. Lastly, the editors avoided making insensitive pronouncements and, in the process, they and their correspondents prevented the spread of Islamophobia in South Africa and across the region.

\section{References}

Abadi, H. (ed.) 2018. Countering the Islamophobia industry: Toward more effective strategies. Atlanta: The Carter Center.

Abbas, T. 2019. Islamophobia as the hidden hand of structural and cultural racism. In Zempi, I. \& I. Awan (eds.): The Routledge International Handbook of Islamophobia. London: Taylor \& Francis.

Ali, W., E. Clinton, M. Duss, L, Fang, S. Keyes, \& F. Shakir 2011. Fear, Inc.: The roots of Islamophobia network in America. Washington: Center for American Progress.

Al-Qalam. 2001. Monthly Issue 27, 8. September 2001. Available at: http://alqalam.co.za/. (Accessed on 20 March 2020.)

Asmal, F. 2008. Islamophobia and the media: The portrayal of Islam since 9/11 and an analysis of the Danish cartoon controversy in SA. PhD thesis, Department of Journalism, University of Stellenbosch, Stellenbosch.

Baderoon, G. 2005. South Africa: Pagad, Islam and the challenge of the local. Equid Novi 26, 1: 85-107.

Bayrakli, E. \& F. Hafez (eds.) 2018. European Islamophobia Report 2017. Ankara: SETA.

Bazian, H. n.d. Islamophobia research \& documentation project. Center for Race \& Gender. Available at: https://www.crg.berkeley.edu/research/ islamophobia-research-documentation-project/. (Accessed on 25 April 2020.)

Bell, A. 1991. The language of news media. Oxford: Blackwell.

Bonyadi, A. \& M. Samuel 2013. Headlines in newspaper editorials: A contrastive study. Sage Open 3, 2: 1-10. doi: 10.1177/215824401349 4863. 
Botha, N. \& A. De Beer 2007. Between Scylla and Charybdis: 911 in South African media. In Pludowski, T. (ed.): How the world's news media reacted to 911. New York: Marquette Books.

Broder, D.S. 2000. Behind the front page. New York: Simon \& Schuster.

Buccus, I. \& L. Nadvi 2006. Resisting the anti-terrorism bill: The role of civil society in legislative reform. Critical Dialogue 2, 1: 18-23.

Cesari, J. 2006. Securitization and religious divides in Europe: Muslims in Western Europe after 9/11: Why the term Islamophobia is a predicament rather than an explanation. Paris: European Commission (PCRD). URL: http://www.antoniocasella.eu/nume/Cesari_2006.pdf.

Conboy, M. 2007. The language of the news. New York: Routledge.

CAIR (Council on American-Islamic Relations). 2010. Islamophobia and its impact in the United States: Same hate, new targets. Washington: CAIR.

De Waal, S. 2010. 25 years of the Mail \& Guardian. Cape Town: Tafelberg Publishers.

Dreyer, N. 2006. A century of Sundays: 100 years of breaking news in the Sunday Times, 1906-2006. Cape Town: Zebra.

Ebrahim, H. 2008. A critical analysis of the discourses on Muslims in the media before and after the events of September 11, 2001. MA dissertation, Department of Psychology, Wits University, Johannesburg.

Githens-Mazer, J. \& R. Lambert 2010. Islamophobia and anti-Muslim hate crime: A London case study. Exeter: European Muslim Research Centre.

Gottschalk, K. 2005. Vigilantism vs. the state: A case study of the rise and fall of PAGAD, 1996-2000. Pretoria: ISS. Paper No. 99.

Hadland, A. 2007. The South African print media, 1994-2004: An application and critique of comparative media systems theory. $\mathrm{PhD}$ thesis, Centre for Film \& Media Studies, UCT, Cape Town.

Hall, D.R. 2001. Materials production: Theory and practice. In Hall, D.R. \& A. Hewings (eds.): Innovations in English language teaching. London: Routledge.

Haron, M. 2003. Undercounting or over-counting South Africa's Muslims: The era of democracy (censuses of 1996 and 2001). Journal for Islamic Studies 23: 100-110.

Haron, M. 2018. Experience of Muslims in South Africa: Historical perspec- 
tives. In Woodward, M. \& R. Lukens-Bull (eds.): Handbook of contemporary Islam and Muslim lives. Perth: Springer.

Hendricks, N. 2020. Terrorism in Africa. London: Palgrave MacMillan.

Henrico, R. 2019. Proselytising the regulation of religious bodies in South Africa: Suppressing religious freedom. Potchefstroom Electronic Law Journal 22. 27 pages. doi: http://dx.doi.org/10.17159/1727-3781/2019/ v22i0a5315.

Herman, E.S. \& N. Chomsky [1988] 2002. Manufacturing consent: The political economy of the mass media. Rev. ed. New York: Pantheon.

Hoover, S. 2006. Religion in the media age. London: Routledge.

Huntington, S. 1993. The clash of civilizations? Foreign Affairs 72, 3: 22-49.

Huntington, S. 1997. The clash of civilizations - and the remaking of world order. London: Touchstone.

Jackson, G.S. 1993. Breaking the story: The South African press. Boulder: Westview Press.

Le, E. 2010. Editorials and the power of the media. Amsterdam: John Benjamins.

Lean, N. 2017. The Islamophobia industry: How the right manufactures hate for the Muslims. $2^{\text {nd }}$ ed. London: Pluto Press.

Lean, N. 2019. The debate over the utility and precision of the 'term' Islamophobia. In Zempi, I. \& I. Awan (eds.): The Routledge International Handbook of Islamophobia. London: Taylor \& Francis.

Kandjii, K. (ed.) 2001. So this is democracy? State of the media in Southern Africa 2000. Windhoek: MISA.

Merrit, C. \& C. Saunders 2000. Weekly Mail (ca. 1985-1994). In Switzer, L. \& M. Adhikari (eds.): South Africa's resistance press: Alternative voices in the last generation of apartheid. Athens: Ohio University Press.

MG (Mail \& Guardian). 2001a. Advertorial. $M G$ 26: 28-29. August 31 to September 6, 2001. Available at: https://mg.co.za/. (Accessed on 20 April 2020.)

MG (Mail \& Guardian). 2001b. Various articles. $M G$ 26: 17, 37. September 14-20, 2001. Available at: https://mg.co.za/. (Accessed on 20 April 2020.)

Poole, E. 2002. Reporting Islam: Media representations of British Muslims. New York: I.B. Tauris Publishers. 
Powell, K. 2011. Framing Islam: An analysis of US media coverage of terrorism since 9/11. Communication Studies 62, 1: 90-112.

Pludowski, T. (ed.) 2007. How the world's news media reacted to 911. New York: Marquette Books.

Runnymede Trust (Commission on British Muslims and Islamophobia). 1997. Islamophobia: A challenge for us all: Report of the Runnymede Trust Commission on British Muslims and Islamophobia. London: Runnymede Trust.

Saeed, T. 2016. Islamophobia and securitization: Religion, ethnicity and the feminine voice. London: Palgrave Macmillan.

Sagheer, S. n.d. Editorial: Definition, importance and types. Sociology Group. Available at: https://www.sociologygroup.com/editorial-definition-importance-types/. (Accessed on 20 April 2020.)

Said, E. 1981. Covering Islam: How the media and the experts determine how we see the rest of the world. London: Routledge.

Said, E. 1987. Orientalism: Western conception of the Orient. London: Verso.

Sayyid, S. 2010. Out of the devil's dictionary. In Sayyid, S. \& A. Vakil (eds.): Thinking through Islamophobia: Global perspectives. London: Hurst \& Co.

Schoeman, W.J. 2017. South African religious demography: The 2013 General Household Survey. HTS Teologiese Studies/Theological Studies 73(2), a3837. 7 pages. doi: https://doi.org/10.4102/hts.v73i2. 3837.

Smith, C. 2013. Anti-Islamic sentiment and media framing during the $9 / 11$ decade. Journal of Religion \& Society 15: 1-15.

ST (Sunday Times). 2001a. Editorial. September 16, 2001. Available at: https://www.timeslive.co.za/sunday-times/. (Accessed on $20 \mathrm{March}$ 2020.)

ST (Sunday Times). 2001b. September 23, 2001. Available at: https:// www.timeslive.co.za/sunday-times/. (Accessed on 20 March 2020.)

ST (Sunday Times). 2001c. September 30, 2001. Available at: https:// www.timeslive.co.za/sunday-times/. (Accessed on 20 March 2020.)

Switzer L. \& M. Adhikari (eds.) 2000. South Africa's resistance press: Alternative voices in the last generation of apartheid. Athens: Ohio University Press. 
Tayob, A.-K. 2002. The South African Muslim community's response to September $11^{\text {th }}$. Annual Review of Islam in South Africa 5: 20-25.

Tellis, A.J. 2004. Assessing America's war on terror: Confronting insurgency, cementing primacy. NBR Analysis 15, 4. Washington: National Bureau of Asian Research with Carnegie Endowment for International Peace.

Tomaselli, K. \& H. Dunn (eds.) 2001. Media, democracy and renewal in Southern Africa. Colorado Springs: International Academic Publishers.

Tomaselli, K., R. Tomaselli, \& J. Muller 1987. Narrating the crisis: Hegemony and the South African press - addressing the nation. Johannesburg: Richard Lyon \& Co.

Vahed, G. \& S. Jeppie 2005. Multiple communities: Muslims in postapartheid South Africa. In Daniel, J., R, Southall, \& J. Lutchman (eds.): The state of the nation: South Africa 2003-2004. Cape Town: HSRC Press.

Van Dijk, T.A. 1995. Discourse semantics and ideology. Discourse and Society 6: 243-289.

Worldometer. n.d. South Africa demographics. Available at: https://www.worldometers.info/demographics/south-africademographics/. (Accessed on 20 April 2020.)

Zelizer, B. \& S. Allan (eds.) 2002. Journalism after September 911. London: Routledge.

Zempi, I. \& I. Awan (eds.) 2019. The Routledge International Handbook of Islamophobia. London: Taylor \& Francis.

Prof Muhammed Haron Department of Theology and Religious Studies

University of Botswana

Gaborone

Faculty of Theology University of Stellenbosch Stellenbosch HARONM@UB.AC.BW 